\title{
The Future of Cohesion Policy in England: Local Government Responses to Brexit and the Future of Regional Funding*
}

\author{
El futuro de la Política de Cohesión en Inglaterra: \\ Respuestas del gobierno local al Brexit \\ y el futuro de la financiación regional
}

\author{
Christopher Huggins \\ University of Aberdeen \\ christopher.huggins@abdn.ac.uk
}

doi: http://dx.doi.org/10.18543/ced-58-2018pp131-153

Summary: I. Introduction.-II. Context: English local government and EU regional policy.-III. Local perspectives during the referendum campaign. 1. Structural constraints. 2. The centralized nature of the referendum campaign. 3. Local politics. -IV. Local perspectives after the referendum. - V. Surveying local authorities' attempts to influence postBrexit regional policy.-VI. Conclusions.

\begin{abstract}
Brexit presents English local authorities with significant uncertainties. This is particularly the case with EU regional policy, which, in a context of political centralization and budgetary pressures, has become an important means for local authorities to undertake projects in their local areas. While local authorities were relatively quiet during the referendum campaign, there is now concern about the long-term future and availability of regional policy support. This article offers an initial survey of local authorities' role during the campaign and their attempts to influence post-Brexit regional policy. It shows that local authorities' attempts to engage in these debates, both before and after the referendum campaign, have been hampered by inherent centralization in the English political system.
\end{abstract}

Keywords: Brexit; EU funding; local government; regional policy.

Resumen: La salida del Reino Unido (UE) de la Unión Europea (UE), el "Brexit", suscita enormes incertidumbres a las autoridades locales inglesas. Es el caso, en particular de la política regional de la UE, que en los últimos años se ha transformado en una importante fuente de apoyo financiero para los proyectos de ámbito local, en un contexto de creciente centralización política y ajuste 
presupuestario. Si bien durante la campaña del referéndum, las autoridades locales permanecieron relativamente tranquilas, en estos momentos se observa una gran preocupación sobre el futuro y la disponibilidad del apoyo de la política regional de la UE. Este artículo aporta una visión inicial sobre el papel jugado por las autoridades locales durante la campaña y sus intentos por influir en la politica regional tras el Brexit. El artículo muestra como los intentos de las autoridades locales por implicarse en estos debates, antes y después de la campaña del referéndum, han sido obstaculizados por una inherente centralización del sistema político inglés.

Palabras clave: Brexit; financiación UE; gobierno local; política regional.

\section{Introduction}

The United Kingdom's (UK) withdrawal from the European Union (EU) presents significant challenges for local government. Local authorities have undergone a significant process of Europeanization, particularly since the late 1980s, and are arguably one of the most Europeanized parts of the British state. ${ }^{1}$ They are directly responsible for the implementation of around 70 per cent of EU legislation and policy. EU rules, such as on procurement and state aid, affect the way they deliver local services. Through the Committee of the Regions, the local level is formally recognized in the EU's institutional structure and has a formal consultative role in the EU policy process. The EU also provides opportunities for local government to informally engage beyond its territorial limits, and local authorities have taken advantage of these, setting up offices in Brussels to lobby EU institutions, and engaging in transnational networks providing platforms to influence EU policy and share policy innovation and best practices with European partners.

On top of this, local authorities have also been the primary beneficiaries of EU regional funding. This financial support has become increasingly important to local authorities in a context of reducing local budgets and

${ }^{1}$ Mike Goldsmith and Elizabeth Sperling, "Local governments and the EU: the British experience". In European Integration and Local Government, ed. by Mike Goldsmith and Kurt Klausen (Cheltenham: Edward Elgar, 1997). Christopher Huggins "Subnational transnational networking and the continuing process of local-level Europeanization", European Urban and Regional Studies OnlineFirst (2017). Peter John "Europeanisation in a centralising state: multi-level governance in the UK", Regional and Federal Studies 6, No. 2 (1996). Adam Marshall "Europeanization at the urban level: Local actors, institutions and the dynamics of multi-level interaction", Journal of European Public Policy 12, No. 4 (2005). 
increased pressures on local public services. The potential loss of EU regional policy finding post-Brexit, therefore, puts local authorities in a position of great uncertainty.

Emerging research is starting to examine the future of post-Brexit regional policy, ${ }^{2}$ but little is being done to understand how local authorities - the primary beneficiaries of EU regional funding - are engaging with this issue themselves. This article addresses this gap in two ways. Firstly, it examines the role of local authorities during the EU referendum campaign, finding that despite the importance of EU regional policy to them, they remained neutral. Secondly, it surveys how local authorities are responding Brexit and the potential loss of EU regional policy support. In contrast to other analysis on post-Brexit regional policy and the impact of Brexit on the local level, the focus here is on the perspectives of local authorities themselves.

Overall, the article finds that local authorities' experience before and after the EU referendum fits the longer-term centralization narrative dominating English local governance. This was evident both during the campaign itself and in local authorities' ongoing efforts to influence postBrexit regional policy. During the campaign local authorities' lack of resources and independent authority, coupled with a centralization of the political debate during the campaign, served to prevent local issues, including the impact of EU funding, from being discussed. While local authorities have become more vocal on EU funding and the need to replace it since the referendum result, their efforts continue to be hampered by national political indifference to the views of local government.

The article's findings are drawn from an initial analysis of local government policy documents and reports published since the 2016 referendum, and from seven interviews with senior local government officials and councillors. These interviews were conducted as part of a pilot study into how local authorities are responding to Brexit. All data gathered from participants was anonymized. Fieldwork took place between July and August 2017.

While Brexit affects local authorities across the UK, the focus here is on English local government. The nature of asymmetric devolution in the UK means local government arrangements differ across the country. In Northern Ireland, Scotland and Wales the devolved administrations have

2 John Bachtler and Iain Begg "Cohesion policy after Brexit: The Economic, Social and Institutional Challenges", Journal of Social Policy 46, No. 4 (2017). Olivier Sykes and Andreas Schulze Bäing "Regional and Territorial Development Policy after the 2016 EU Referendum - Initial Reflections and some Tentative Scenarios", Local Economy 32, No. 3 (2017). 
responsibility for local government, whereas in England, where there has not been any substantive devolution, local government remains controlled by the UK central government in Westminster. Focusing on English local authorities, therefore, allows the question of the future of regional policy to be explored with reference to the longer-term centre-local relationship in England.

The article proceeds as follows. The next section contextualizes English local government, noting local authorities operate in a highly centralized political system and are faced with significant budgetary challenges. As a result of this EU regional funding has become an important resource for them, providing not only financial assistance, but a range of non-pecuniary benefits too. The absence of local authorities from the EU referendum debate is then noted, and three factors which account for this absence - structural constraints, the centralized nature of the campaign and the realities of local politics - are then summarized. Local perspectives after the referendum are then surveyed, showing that local authorities have called on the government to replace EU regional funding, but also to use Brexit as an opportunity to ensure any future funding arrangements better fit local needs and are less administratively burdensome. Noting that local authorities still lack clarity over what post-Brexit regional policy support will look like, the final section surveys how they have engaged with the debate on post-Brexit regional policy support. This finds that while local authorities have been active in lobbying the government and calling for EU funding to be replaced, their success remains hampered by inherent centralization in the English political system.

\section{Context: English local government and EU regional policy}

Local government in England operates in a highly centralized political system, where local authorities have limited capacity to act and are largely dependent upon central government for financial support.

The centralized nature of local government in England has been the focus of much research. ${ }^{3}$ English local authorities lack independent legislative capacity and have limited policy making powers, and most of their work is restricted to implementing UK government policy. This means local authorities might be better thought of as 'local administration', rather than 'local government'. Indeed, by one measure, the UK is $31^{\text {st }}$ on an index

3 Colin Copus, Mark Roberts and Rachel Wall, Local Government in England: Centralisation, Autonomy and Control (Basingstoke: Palgrave Macmillan, 2017). 
of the local autonomy of 39 European countries. ${ }^{4}$ While there have been efforts to devolve powers to local authorities, aimed primarily at English city-regions, these attempts are confined to a relatively small number of areas. This devolution agenda has also been criticized for being led from the top-down, lacking adequate consultation and citizen engagement, lacking policy ambition, and failing to give devolved areas the necessary resources to take on the additional policy responsibilities given to them. ${ }^{5}$

English local authorities also lack constitutional protection. As a result, local authorities find themselves in a constantly fluctuating institutional environment, where their role and existence is frequently contested and changed. In recent years this has been illustrated with the abolition of regional development agencies (RDAs), followed by the creation of Local Enterprise Partnerships (LEPs), ${ }^{6}$ and more recently moves towards city deals and combined authorities. ${ }^{7}$ This has led to a confusing patchwork of multiple, inconsistent and overlapping geographies at the local level.

This fluctuating institutional landscape, and especially the abolition of the RDAs, has significant implications for the local level impact of EU regional policy in England. The RDAs played an important role in administering EU regional funding and the presence of local authority representation on RDA boards ensured there was local oversight over the management of EU funds. Following their abolition in 2010, the RDAs' role in the management of EU funding in England was transferred to the central government. RDAs were replaced with LEPs, which were given a role in EU regional policy by having to establish local strategies for how EU Structural and Investment funds should be spent. However, the LEPs' were given limited room for manoeuvre in deviating from centrally prescribed strategic objectives. ${ }^{8}$ Overall, then, the management

4 "Self-rule Index for Local Authorities", Committee of the Regions, accessed 9 February 2018, http://ec.europa.eu/regional_policy/en/information/publications/studies/2015/ self-rule-index-for-local-authorities-release-1-0

5 David Blunkett, Matthew Flinders and Brenton Prosser "Devolution, Evolution, Revolution ... Democracy? What's Really Happening to English Local Governance?", The Political Quarterly 87, No. 4 (2016). Brenton Prosser et al. "Citizen Participation and Changing Governance: Cases of Devolution in England", Policy and Politics 45, No. 2. (2017).

${ }^{6}$ Lee Pugalis and Ben Fisher "English regions disbanded: European funding and economic regeneration implications", Local Economy, 26, No. 6-7 (2011).

7 Mark Sandford, Combined authorities (London: House of Commons Library, 2016). Mark Sandford, Devolution to Local Government in England (London: House of Commons Library, 2016).

8 Christopher Huggins "Local Enterprise Partnerships and the Development of European Structural and Investment Fund Strategies in England", European Structural and Investment Funds Journal, 2, No. 2 (2014). 
and oversight of EU funding has become increasingly centralized, and the frequent reorganization of the institutions responsible for economic development has meant the England has struggled to develop a coherent and long-term approach to regional policy. ${ }^{9}$

This inherent centralization is also reflected in local authorities' available resources. Local authorities draw most of their income from two sources: a 'council tax' which is locally levied and collected, and grants provided by the central government. During 2016-17, 57.5 per cent of local authority budgets were financed through central government grants. ${ }^{10}$ Only 28 per cent was funded through locally collected council tax. ${ }^{11}$ Furthermore local authorities are encouraged to keep annual council tax rises to a minimum, and if the rate increases by a certain level set by the government (currently 4 per cent or 2 per cent depending on the type of authority) a local referendum must be held to ratify the increase. Local authorities are therefore largely dependent upon the central government for financial resources. This dependence has been exacerbated in recent years by a programme of austerity pursued by the UK government. This has seen central government grants to local authorities drastically decrease and has led to significant pressures on local budgets at a time when demand for local services, such as social care, is increasing. Indeed, between 2010-11 and 2014-15, local authorities saw their spending power reduced by 27 per cent. ${ }^{12}$

It is in this context of high centralization, institutional instability and public finance pressures, then, that English local authorities have become significant beneficiaries of EU regional funding. To the UK as a whole, the European Regional Development Fund is worth $€ 5.8$ billion during the

9 Andrew Jones "Here We Go Again: The Pathology of Compulsive Re-organisation", Local Economy, 25, No. 5-6 (2010). Lee Pugalis "Sub-national economic development: Where do we go from here?", Journal of Urban Regeneration and Renewal, 4, No. 3 (2011). Lee Pugalis "The Regional Lacuna: A Preliminary Map of the Transition from Regional Development Agencies to Local Enterprise Partnerships", Regions, 281 (2011). Lee Pugalis and Adam Townsend "Rebalancing England: sub-national development (once again) at the crossroads", Urban Research and Practice, 5, No. 1 (2012).

10 "Local Authority Revenue Expenditure and Financing: 2016-17 Final Outturn, England", Department for Communities and Local Government, accessed 9 February 2018, https://www.gov.uk/government/uploads/system/uploads/attachment_data/file/659752/RO_ Final_Outturn_2016-17_Statistical_Release.pdf

11 "Council Tax Levels Set by Local Authorities: England 2017-18", Department for Communities and Local Government, accessed 9 February 2018, https://www.gov.uk/ government/uploads/system/uploads/attachment_data/file/603781/Council_tax_levels_set_ by_local_authorities_in_England_2017-18.pdf

12 Annette Hastings et al., The Cost of the Cuts: The Impact on Local Government and Poorer Communities (York: Joseph Rowntree Foundation, 2015). 
2014-2020 programming period. This funding is supplemented by national co-financing, meaning its true value is $€ 10.3$ billion. Local communities also benefit from a range of other European structural and investment funds, including the European Social Fund (worth $€ 8.7$ billion including national co-financing), the European Agricultural Fund for Rural Development ( $€ 7.3$ billion including national co-financing) and the Youth Unemployment Initiative ( $€ 600$ million including national co-financing). ${ }^{13}$ While this funding is unevenly distributed across the UK, reflecting uneven levels of regional development, data from the last programming period (2007-2013) shows that all local areas in England received EU regional funding support. ${ }^{14}$

In a context where local services are under considerable pressure, and while local authorities are simultaneously seeing their budgets fall, this EU funding has provided an alternative source of income for local authorities to deliver local projects they otherwise would not have been able to afford. The benefits of EU funding to local authorities also goes beyond pure pecuniary terms, with projects often having an 'added value' beyond the funding received, such as the exchange of policy knowledge and innovation and research into local policy problems. Many projects have also been used as the basis for developing lasting partnerships and collaborations with local authorities in other European countries. ${ }^{15}$

\section{Local perspectives during the referendum campaign}

Despite the importance of EU regional funding to local areas, and indeed the impact of the EU more broadly on local government, local authorities were surprisingly quiet during the referendum campaign. Indeed, all participants interviewed noted their respective local authorities remained neutral during the EU referendum campaign. Representative organizations, such as the English Local Government Association (LGA), also took a neutral stance. ${ }^{16}$ The result of this is a retrospective perception

13 "European Structural and Investment Funds: Country Data for United Kingdom", European Commission, accessed 9 February 2018, https://cohesiondata.ec.europa.eu/ countries/UK

14 "Evaluations of the 2007-2013 programming period", European Commission, accessed 9 February 2018, http://ec.europa.eu/regional_policy/en/policy/evaluations/ec/2007-2013/

15 Christopher Huggins "Subnational transnational networking and the continuing process of local-level Europeanization”, European Urban and Regional Studies OnlineFirst (2017).

16 "Briefing, Leaving the European Union", Local Government Association, accessed 4 July 2016, http://www.local.gov.uk/web/guest/media-releases/-/journal_ content/56/10180/7870973/NEWS 
by local authorities that they could have done more to engage with the debate, ${ }^{17}$ and that they failed to adequately explain the benefits brought by EU funding to their local areas. ${ }^{18}$

Three reasons account for this lack of engagement during the campaign: structural constraints, the centralized nature of the referendum campaign, and the realities of local politics.

\section{Structural constraints}

Local authorities were first presented with a legal barrier during the pre-election period, also known as 'purdah'. During this period, held before all elections and referendums in the UK, local authorities are bound by a code of practice which prevents them from issuing any communication or publicity which may be seen to influence voters. ${ }^{19}$ Local authorities have often applied this code of practice in a risk averse way to avoid complaints.

The purdah period for the EU referendum began on 27 May 2016, and, in the four weeks preceding the referendum, effectively prohibited local authorities from publishing any material related to the referendum or which could be perceived to influence voters. Some local authorities also held local elections in May 2016, with the pre-election period starting on 27 March $2016 .{ }^{20}$ The effect of this was a prolonged period spanning three months, where local authorities were not permitted to engage with the referendum debate. The presence of these rules, and the fact local authorities were responsible for administering the poll, meant even outside of the purdah period local authorities were reluctant to engage in the debate as it was not deemed to be their place to do so. ${ }^{21}$

Outside of this extended purdah period, local authorities were faced with another structural barrier preventing them from playing an active role in the referendum campaign: a lack of resources. As noted in Section II above, local authorities have been subject to ever decreasing budgets and spending power at a time when demand for their primary services has been increasing. As a result, many local authorities did not have the capacity,

17 Senior local authority official, interview with the author, 31 July 2017.

${ }_{18}$ Former council leader, interview with the author, 11 July 2017. Senior local authority official, interview with the author, 25 August 2017.

19 "Code of Recommended Practice on Local Authority Publicity", Department for Communities and Local Government, accessed 9 February 2018, https://www.gov.uk/ government/uploads/system/uploads/attachment_data/file/5670/1878324.pdf

20 Neil Johnson, 'Purdah' before elections and referendums (London: House of Commons Library, 2017).

${ }^{21}$ Senior local authority official, interview with the author, 18 August 2017. 
both in terms of financial and staff resources, necessary to analyse the impact of the EU on their local areas and engage with the campaigns.

\section{The centralized nature of the referendum campaign}

Despite the impact of the EU on local government, local issues were not the main focus of the referendum campaign. Rather the campaign focused on national political issues which had dominated long-standing debates on the UK's relationship with the EU, such as immigration, sovereignty over decision-making, the economy and the cost of EU membership. ${ }^{22}$ Those national issues nevertheless have a local impact, but this was never articulated in the referendum debate, nor was local knowledge sought by the main campaigns. Indeed, one interviewee noted their local authority had produced analysis on the impact of the EU on their local area and had offered it freely to both the 'remain' and 'leave' campaigns, but were rebuffed by both. ${ }^{23}$ When the campaigns held local events, national political figures were often 'parachuted in', rather than drawing on local political figures. ${ }^{24}$

This partly reflects a centralization of political debate in England. Indeed, both the official campaigns (Britain Stronger In Europe for 'remain' and Vote Leave for 'leave') were centralized and led by prominent national political figures, and there was a perception among local actors that those involved in the organization of the campaigns saw local government as nothing more than 'toy town politics' ${ }^{25}$ Opportunities for local politicians to be given a platform and campaign, for either side, in the referendum based on local issues were therefore limited. As one local official reflected: 'I don't think any of the core issues that were needed to have been understood by local people in the local areas were really picked up on as part of either of the campaigns' ${ }^{26}$ There was also scepticism about whether the involvement of local authorities or the communication of local issues would have made a difference to the overall referendum result. ${ }^{27}$

${ }^{22}$ Harold Clarke, Matthew Goodwin and Paul Whiteley, Brexit: Why Britain Voted to Leave the EU (Cambridge: Cambridge University Press, 2017). Geoffrey Evans and Anand Menon, Brexit and British Politics (Cambridge: Polity Press, 2017).

23 Senior local authority official, interview with the author, 31 July 2017.

${ }^{24}$ Former council leader, interview with the author, 11 July 2017.

25 Council leader, interview with the author, 23 August 2017.

${ }^{26}$ Senior local authority official, interview with the author, 31 July 2017.

27 Senior local authority official, interview with the author, 18 August 2017. Senior local authority official, interview with the author, 31 July 2017. 
On top of this, the focus on the national debate meant that the possibility of a leave vote was not taken seriously by some local authorities. Consequently many local authorities did not consider undertaking any analysis of the referendum or its possible outcomes. As one local official noted: 'there was no resource which went into investigating the likely impact or costs [of a leave vote] on the local picture' ${ }^{28}$

\section{Local politics}

Local political realities also prevented local authorities from playing an active role in the campaign. Analysis of voter behaviour in the EU referendum shows that the way people voted transcended traditional party allegiances and left-right politics. Voters instead were split along the lines of social values, age and education. ${ }^{29}$ This applied equally to local government, and meant local authorities as a whole remained neutral. As noted by the LGA: 'local government holds a range of views about the future of Britain's membership of the EU which is why the LGA remained neutral during the referendum' ${ }^{30}$ This applied within, as well as across, local authorities. Indeed, because Brexit cut across party political lines, many local leaders were wary of the potential for splits within their own cabinets ${ }^{31}$ or the potential for fragile governing coalitions to collapse ${ }^{32}$ Many council leaders therefore pursued a policy of active neutrality in the referendum debate. As noted by one local authority leader: 'from a party political perspective ... it was better to just leave it alone' ${ }^{33}$

The presence in some areas of local elections in the month preceding the referendum also had an impact. In addition to extending the purdah period for local authorities, local politicians were concerned that the referendum debate would overshadow local democracy, with voters using local elections as a 'dry run' of the referendum rather than focusing on local political issues. As one local official noted: 'councillors were afraid to nail their colours to the mast in case it put their chances of re-election at risk' ${ }^{34}$

${ }^{28}$ Senior local authority official, interview with the author, 18 August 2017.

${ }^{29}$ Harold Clarke, Matthew Goodwin and Paul Whiteley, Brexit: Why Britain Voted to Leave the EU (Cambridge: Cambridge University Press, 2017).

30 "Briefing, Local Government Association, Brexit", Local Government Association, accessed 17 December 2016, https://www.local.gov.uk/sites/default/files/documents/lgabriefing-local-govern-0ff.pdf

31 Council leader, interview with the author, 23 August 2017.

32 Former council leader, interview with the author, 11 July 2017.

33 Council leader, interview with the author, 23 August 2017.

${ }^{34}$ Senior local authority official, interview with the author, 31 July 2017. 
As a result of both the potential for splits within local authority cabinets and the perceived risk to local elections, local politicians gave officials a moratorium on providing any EU-related information in the months preceding the referendum. Many local authorities had information about the impact of the EU at the local level, but were prevented from releasing it to the public. As one local official recalled: 'I was told not to put that information out there and to take a completely neutral view' ${ }^{35}$

\section{Local perspectives after the referendum}

While local authorities had been quiet during the referendum campaign, they became very vocal once the result was declared. In the immediate aftermath they quickly began to warn of the potential loss of regional funding provided by the EU. The LGA highlighted the risk of losing EU funding allocated during the 2014-2020 programming period and issued a call for the government to guarantee and protect it. ${ }^{36}$ This was similarly reflected in interviews, with all participants highlighting that the loss of EU funding was a key risk associated with Brexit.

The short-term focus for local authorities was to ensure spending allocated in the current 2014-2020 programming period would be honoured if the UK left the EU before the end of 2020, as this would have a direct impact on projects which local authorities had already been awarded funding for and their ability to bid for projects in the current programming period. In October 2016 the UK government confirmed it would underwrite the cost of projects approved while the UK was still an EU member state providing they represented 'good value for money', and 'are in line with domestic strategic priorities'. ${ }^{37}$ This commitment was extended following the conclusion of first phase of the exit negotiations between the UK and EU in December 2017, which allows the UK to continue participating in all EU-funded programmes financed by the current multi-annual financial framework, until the end of $2020 .^{38}$

35 Senior local authority official, interview with the author, 31 July 2017.

36 "Briefing, Leaving the European Union", Local Government Association, accessed 4 July 2016, http://www.local.gov.uk/web/guest/media-releases/-/journal_ content/56/10180/7870973/NEWS

37 "Further certainty on EU funding for hundreds of British projects", HM Government, accessed 9 February 2018, https://www.gov.uk/government/news/further-certainty-on-eufunding-for-hundreds-of-british-projects

38 "UK-EU joint report: Phase 1 Negotiations Briefing", Local Government Association, accessed 9 February 2018, https://www.local.gov.uk/sites/default/files/documents/2017\%20 $12 \% 2011 \% 20$ LGA $\% 20$ briefing $\% 20-\% 20$ EU\% 20 Phase $\% 201 \% 20$ agreement $\% 20$ briefing $\% 20$ $\% 28002 \% 29$.pdf 
There are questions, however, about the longer-term availability of regional funding and cohesion policy support beyond 2020. While cohesion policy and the principles of regional solidarity are established in the EU, Conservative governments in London have prioritized austerity and limits to public spending. Furthermore, as highlighted in Section II, the constantly fluctuating institutional environment has meant England has struggled to embed a coherent and long-term approach to regional policy. This has led to questions over whether the UK will continue to invest in its regions post-Brexit, at least to the same level the EU has. ${ }^{39}$ Indeed, one participant highlighted that EU funding was allocated to regions on the basis of need, whereas national funding schemes were more limited, more competitive and often subject to political interference. ${ }^{40}$

However, while there has been widespread concern among local authorities at the potential loss of funding and the benefits it brings, there is also a sense that Brexit provides an opportunity to revisit how regional support is prioritized and administered. Indeed, while EU funding has been of considerable benefit to English localities, it has also been a source of frustration. Often the objectives of EU funding programmes do not directly match local needs, or the aims and objectives in council strategies. Local authorities generally will not change their pre-determined strategic objectives just to ensure projects fit EU funding criteria. For most bids, especially those by authorities in 'more-developed regions', funding only covers a proportion of the total project costs (usually 50 per cent), meaning local authorities have to find the rest. In a context of tight budgets, finding this necessary match funding from within local authority budgets is often difficult, and if co-finance cannot be obtained from other sources then the project will not go ahead.

In addition, local authorities have been critical of the onerous reporting, audit and management of EU grants. This has been acknowledged by the European Commission itself, which has taken steps to simplify cohesion policy, ${ }^{41}$ though despite these efforts the system overall remains highly complex. ${ }^{42}$ This complexity and administratively

39 "Re-inventing regional policy for post-Brexit Britain", Kevin Morgan, accessed 9 February 2018, http://blogs.cardiff.ac.uk/brexit/2017/04/26/re-inventing-regional-policy-forpost-brexit-britain/

${ }^{40}$ Former council leader, interview with the author, 11 July 2017.

41 "Simplifying Cohesion Policy for 2014-2020", European Commission, accessed 9 February 2018, http://ec.europa.eu/regional_policy/sources/docgener/informat/2014/ simplification_en.pdf

42 "Is simplification simply a fiction?", Sara Davies, accessed 9 February 2018, https:// strathprints.strath.ac.uk/58784/1/Davies_IQ_Net_2015_Is_simplification_simply_a_fiction. pdf 
burdensome process, coupled with a high risk in some programmes of bids being unsuccessful, has put many local authorities off applying for EU funding in the first place.

For local authorities and the availability of EU funding, then, Brexit presents both a threat and an opportunity. On the one hand the potential loss of EU funding, especially at a time when local authority budgets are already under pressure, presents a significant risk, especially if funding is not replaced to the levels currently provided by the EU. On the other hand, if funding is replaced there is an opportunity for it to better meet local needs and addresses local authorities' concerns regarding its administration and implementation. To this end, the LGA has called for a regional funding programme post-Brexit which is at least equal to the current value of EU structural and investment funds, which is simpler and adopts a more proportionate approach to financial management, and which focuses on addressing locally identified priorities. Given the 'added value' offered, the LGA has also called for the government to consider continued participation in cross-border and other collaborative programmes such as Interreg. ${ }^{43}$

After the 2017 general election was called, the LGA called on the main political parties to address these points and outline their proposals for 'successor' regional funding schemes to replace those currently offered by the EU. ${ }^{44}$ The Conservative Party manifesto committed to establishing a 'Shared Prosperity Fund' to replace EU regional funding following the UK's withdrawal from the EU:

We will use the structural fund money that comes back to the UK following Brexit to create a United Kingdom Shared Prosperity Fund, specifically designed to reduce inequalities between communities across our four nations. The money that is spent will help deliver sustainable, inclusive growth based on our modern industrial strategy. We will consult widely on the design of the fund, including with the devolved administrations, local authorities, businesses and public bodies. The UK Shared Prosperity Fund will be cheap to administer, low in bureaucracy and targeted where it is needed most. ${ }^{45}$

43 "Beyond Brexit: Future of Funding Currently Sources from the EU", Local Government Association, accessed 9 February 2018, https://www.local.gov.uk/beyondbrexit-future-funding-currently-sourced-eu-lga-discussion-document

44 "What the Manifestos Say 2017: Brexit, Devolution and Constitutional Reform", Local Government Association, accessed 9 February 2018, https://www.local.gov.uk/ sites/default/files/documents/9\%2038\%20LGA\%20MANIFESTO_BREXIT_v02_1\%20 $\% 28002 \% 29-4$.pdf

45 Conservative Party, Forward Together: Our Plan for a Stronger Britain and a Prosperous Future (London: Conservative Party, 2017), 37 
This commitment was broadly welcomed by local authorities and representative groups such as the LGA and the Industrial Communities Alliance. ${ }^{46}$ In particular, it addressed concerns about the loss of funding, while committing to ensure any new funding arrangements meet local needs and are light on bureaucracy. However beyond the manifesto commitment being made, there has been very little substantive development on the Shared Prosperity Fund. The launch of the government's industrial strategy in November 2017 was seen as an opportunity to provide greater clarity on this, but the strategy itself made little mention of post-Brexit regional funding and support. ${ }^{47}$

Local authorities therefore remain in a state of uncertainty about the future of regional policy support. Indeed as of December 2017, the LGA was continuing to call for 'urgent clarity' on how EU funding will be replaced post-Brexit. ${ }^{48}$

\section{Surveying local authorities' attempts to influence post-Brexit regional policy}

Most political lobbying work to influence the UK government is taking place through the LGA. This organization represents the vast majority of English local authorities (349 out of 352). As noted above, the LGA remained deliberately neutral during the referendum campaign, but, after the result was announced, has become active in ensuring local perspectives on Brexit are communicated.

A week after the referendum result, the LGA announced it was establishing a specialized unit of staff to examine the implications of Brexit for local government and sought the views of its constituent local authorities on what the unit's main priorities should be. ${ }^{49}$ At the political level, the

46 Industrial Communities Alliance, Post-Brexit Regional Policy: Proposal from the Industrial Communities Alliance (Barnsley: Industrial Communities Alliance, 2017). "Beyond Brexit: Future of Funding Currently Sources from the EU", Local Government Association, accessed 9 February 2018, https://www.local.gov.uk/beyond-brexit-futurefunding-currently-sourced-eu-lga-discussion-document

47 "Industrial Strategy: building a Britain fit for the future", HM Government, accessed 9 February 2018, https://www.gov.uk/government/publications/industrial-strategy-building-abritain-fit-for-the-future

48 “'Urgent clarity' needed on EU funds, councils warn”, Local Government Association, accessed 9 February 2018, https://www.local.gov.uk/about/news/urgent-clarityneeded-eu-funds-councils-warn

49 "Briefing, Leaving the European Union", Local Government Association, accessed 4 July 2016, http://www.local.gov.uk/web/guest/media-releases/-/journal_ content/56/10180/7870973/NEWS 
LGA has also set up a Brexit 'Task and Finish Group' composed of local politicians. Given the overall impact of the EU on local government, the LGA's remit on assessing the impact of Brexit has been large, encompassing a range of issues such as the rights of EU workers and prospects for further devolution. Nevertheless a large part of the LGA's work has been focused on the future of EU regional funding. The LGA's short-term objective was to guarantee local authority access to EU funding in the current 2014-2020 programming period. The government's commitment to underwrite projects already approved before the UK's withdrawal from the $\mathrm{EU}^{50}$ therefore represented an early success. However, as discussed above, there remains uncertainty about longer-term regional policy support after Brexit. In July the LGA, together with the support of the Northern Ireland Local Government Association, the Welsh Local Government Association and the Convention of Scottish Local Authorities, published the 'Beyond Brexit' report. ${ }^{51}$ This conducted an analysis of the various EU-funded programmes local authorities engage in and set out a series of preferences for post-Brexit regional policy, as outlined in Section IV above.

All interviewees noted that the LGA was the primary means for local authorities to influence the government on post-Brexit regional policy. Indeed there was an acknowledgement that because of the lack of resources and capacity within local authorities themselves, it was necessary to work together as they would not be able to have an impact if acting individually..$^{2}$ There was also an acknowledgement that the LGA had built up and maintained working relationships with national politicians and civil servants working in government ministries, and was able to use these connections to gain access to and pressure the government. ${ }^{53}$ Nevertheless, there was also an acknowledgement that the LGA had its limits. As a politicallydriven organization, the LGA has to seek agreement from its membership for its policy positions, and with the LGA's large and diverse membership, participants felt this hindered it taking strong positions. Furthermore, like the government itself, the LGA is led by the Conservative Party, and one local authority leader felt there was reluctance within the LGA to be seen to be undermining the governing party, so held back on some policy positions. ${ }^{54}$

50 "Further certainty on EU funding for hundreds of British projects", HM Government, accessed 9 February 2018, https://www.gov.uk/government/news/further-certainty-on-eufunding-for-hundreds-of-british-projects

51 "Beyond Brexit: Future of Funding Currently Sources from the EU", Local Government Association, accessed 9 February 2018, https://www.local.gov.uk/beyondbrexit-future-funding-currently-sourced-eu-lga-discussion-document

52 Senior local authority officer, interview with author, 18 August 2017.

53 Council leader, interview with author, 9 August 2017.

${ }^{54}$ Former council leader, interview with author, 11 July 2017. 
As a result, local authorities are also taking up the issue of post-Brexit regional policy through a range of other associations and networking, including the County Councils Network, the Core Cities Network and the Industrial Communities Alliance. These have tighter and more focused memberships, and so are able to more easily agree on policy positions.

While little work was done before the referendum vote, local authorities have also now started to undertake internal assessments on the impact of Brexit. For example, Cornwall Council and the Isles of Scilly have established a 'Futures Group' and Bristol City Council has set up a 'Brexit Response Group', bringing together partners from the local community to investigate the impact of Brexit on their local areas, including the potential loss of EU funding support. ${ }^{55}$ Nevertheless there is wide variation in the level of work local authorities are putting in, and they ultimately face the same lack of resources to assess the impact of and prepare for Brexit as they did during the referendum campaign. ${ }^{56}$ As one council leader stated: 'at the end of the day we've still got our day job to do, and that comes first'. ${ }^{57}$

While local authorities have now become actively engaged in the debate about post-Brexit regional policy, they continue to face the same significant challenge as they did during the referendum campaign: inherent centralization in the English political system. While there was an acknowledgement that at the technical level junior civil servants have been willing to engage with local government, ${ }^{58}$ at a senior civil service and political level, there is a perception among local authorities that they are not being listened to. Indeed, when asked if they felt the views of local government on Brexit were being taken into account by the government, all participants were universal in their negative reply. While the devolved administrations of Northern Ireland, Scotland and Wales had been actively consulted on Brexit, English local government lacked a seat at the table, which local authorities found concerning. This lack of concern shown to the local level by central government manifested itself in several ways, including national civil servants and government ministers rebuffing invitations to visit local areas and meet

55 "Bristol and Brexit: An initial response to government from the Bristol Brexit Response Group", Bristol City Council, accessed 9 February 2018, https://www.bristol.gov. uk/mayor/bristol-and-brexit. "A Catalyst for Change: Implications, Risks and Opportunities of Brexit for Cornwall and the Isles of Scilly", Cornwall Council, accessed 9 February 2018, https://www .cornwall.gov.uk/media/24227365/catalyst-for-change-brexit-report.pdf

56 Senior local authority official, interview with author, 25 August 2017.

57 Council leader, interview with author, 9 August 2017.

58 Senior local authority official, interview with author, 25 August 2017. 
with local actors to discuss the impact of Brexit on regional funding, and government ministries not replying to requests for information.

These findings corroborate long-standing research into the centrallocal relationship in English politics. Indeed, a recent 'councillors commission' report highlighted that Westminster and Whitehall have little understanding, nor a desire to understand, local councillors' and local government's role..$^{59}$ As one participant observed: 'centralization is at the heart of the government's DNA'. 60

On top of this was a perception that central government itself lacked adequate capacity to handle the complexities of Brexit. For example, local authorities found it difficult to engage with the Department for Exiting the European Union (DExEU) - the government ministry responsible for managing the process of Brexit - as they were still in the process of appointing staff. ${ }^{61}$ One participant noted that: 'DExEU is almost impossible to penetrate - I don't know if this is a conscious decision to keep local government out of the loop or whether they are simply overwhelmed by amount of work' ${ }^{62}$ Wider political instability following the general election in June 2017 and the return of a minority government was also cited as a concern. ${ }^{63}$ In these circumstances there was a perception among local authorities that it was simply easier for the government to adopt a centralizing approach, especially when it was distracted by Brexit. ${ }^{64}$ Nevertheless, there was also a sense that a distracted government presented an opportunity to push local authorities' agenda, provided local authorities themselves had the resources to engage with the government. ${ }^{65}$

Overall, then, developments in national politics are affecting local authorities' attempts to influence the shape of post-Brexit regional policy support. On the one hand, a long-standing culture of centralization in government has meant that despite local authorities' efforts to engage in the debate on post-Brexit regional policy, they are not being listened to. On the other hand, a fundamental lack of capacity within government itself means it is often too distracted take up and respond to the concerns of local authorities.

59 Colin Copus and Rachel Wall The Voice of the Councillor: Final Report of the De Montfort University and Municipal Journal Councillor Commission (Leicester: De Montfort University, 2017).

${ }^{60}$ Senior local authority official, interview with author, 31 July 2017.

${ }_{61}$ Senior local authority official, interview with author, 18 August 2017.

62 Senior local authority official, interview with author, 25 August 2017.

${ }_{63}$ Former council leader, interview with author, 11 July 2017.

${ }^{64}$ Council leader, interview with author, 9 August 2017.

65 Senior local authority official, interview with author, 31 July 2017. 


\section{Conclusions}

The UK's withdrawal from the EU presents significant challenges to local authorities in England. This is especially the case of EU regional policy, which in a context of public finance pressures has become a vital resource for English local authorities. This article, based on a pilot study investigating the impact of Brexit on English local government, sought to present an initial survey of how local authorities have engaged with the debate on the future of regional policy support once the UK leaves the EU.

The primary theme running through this article is of the inherent centralization of the English political system. During the referendum campaign a range of structural constraints and the centralized nature of the campaign, alongside the realities of local politics, prevented local authorities from engaging in the debate. This centralization has continued after the Brexit vote. While local authorities are now actively engaged in the debate about post-Brexit regional policy support, their efforts continue to be hampered by a culture of centralization and a fundamental lack of capacity within the central government itself. The overall effect of this is that, despite the significance of EU regional policy to local authorities, their concerns are not yet being taken into account.

This has significant implications for the future of regional policy support in England, and indeed the longer-term role of local government. As noted, local authorities have faced increasing public finance pressures as demand for local public services increases while local budgets fall. In this context EU regional policy has been an important resource for local authorities to undertake projects in their local areas which they otherwise would not have been able to afford. Furthermore, attempts to embed a long-term approach to regional policy in England have been hampered by continuous changes to the subnational institutional landscape. Without any clarity on the future of regional policy support beyond 2020, coupled with wider debates about the future of devolution and local government finance, local authorities continue to find themselves in a position of great uncertainty.

These concerns are not just confined to England. Work undertaken by the Northern Ireland Local Government Association, the Welsh Local Government Association and the Convention of Scottish Local Authorities stresses the value of EU regional funding to local authorities in their respective territories, and the significant concerns that are present surrounding the long-term availability of regional funding after Brexit. ${ }^{66}$

66 "Stocktake report on UK withdrawal from the European Union (Brexit)", Convention of Scottish Local Authorities, accessed 9 February 2018, http://www.cosla.gov.uk/sites/ default/files/private/leadersmeeting-brexit.pdf. "EU Referendum Outcomes - NILGA 
This shows that, while the focus in this article has been on English local government, the same concerns about the loss of EU funding and its postBrexit successor are being felt by local authorities UK-wide.

Overall, while Brexit has been hailed by some as an opportunity to increase the role of local government and devolve further powers and resources to them, the evidence from English local authorities' engagement in the debate so far suggests the culture of centralization within the English polity continues to persist.

\section{Bibliography}

Bachtler, John and Iain Begg. "Cohesion policy after Brexit: The Economic, Social and Institutional Challenges". Journal of Social Policy 46, No. 4 (2017): 745-763.

Blunkett, David, Matthew Flinders and Brenton Prosser. "Devolution, Evolution, Revolution ... Democracy? What's Really Happening to English Local Governance?". The Political Quarterly 87, No. 4 (2016): 553-564.

Bristol City Council. "Bristol and Brexit: An initial response to government from the Bristol Brexit Response Group". Accessed 9 February 2018. https://www. bristol.gov.uk/mayor/bristol-and-brexit

Clarke, Harold, Matthew Goodwin and Paul Whiteley. Brexit: Why Britain Voted to Leave the EU Cambridge: Cambridge University Press, 2017.

Committee of the Regions. "Self-rule Index for Local Authorities". Accessed 9 February 2018. http://ec.europa.eu/regional_policy/en/information/publications/ studies/2015/self-rule-index-for-local-authorities-release-1-0

Conservative Party. Forward Together: Our Plan for a Stronger Britain and a Prosperous Future London: Conservative Party, 2017.

Convention of Scottish Local Authorities. "Stocktake report on UK withdrawal from the European Union (Brexit)". Accessed 9 February 2018. http://www. cosla.gov.uk/sites/default/files/private/leadersmeeting-brexit.pdf.

Copus, Colin, Mark Roberts and Rachel Wall. Local Government in England: Centralisation, Autonomy and Control Basingstoke: Palgrave Macmillan, 2017.

Copus, Colin and Rachel Wall. The Voice of the Councillor: Final Report of the De Montfort University and Municipal Journal Councillor Commission Leicester: De Montfort University, 2017.

Cornwall Council. "A Catalyst for Change: Implications, Risks and Opportunities of Brexit for Cornwall and the Isles of Scilly". Accessed 9 February 2018. https:// www.cornwall.gov.uk/media/24227365/catalyst-for-change-brexit-report.pdf

Position Paper", Northern Ireland Local Government Association, accessed 9 February 2018, http://www.nilga.org/getattachment/c7253dae-010e-4d6e-8013-d84c70ac4933/EUReferendum-Outcomes---NILGA-Position-Paper.aspx. "Collating Local Impact of Brexit, Spring 2017”, Welsh Local Government Association, accessed 9 February 2018, http://www. wlga.wales/SharedFiles/Download .aspx ?pageid=62\& $\mathrm{mid}=665 \&$ fileid= $=1178$. 
Davies, Sara. "Is simplification simply a fiction?". Accessed 9 February 2018, https://strathprints.strath.ac.uk/58784/1/Davies_IQ_Net_2015_Is_simplification_simply_a_fiction.pdf

Department for Communities and Local Government. "Code of Recommended Practice on Local Authority Publicity”. Accessed 9 February 2018. https://www.gov.uk/government/uploads/system/uploads/attachment_data/ file/5670/1878324.pdf

Department for Communities and Local Government. "Council Tax Levels Set by Local Authorities: England 2017-18”. Accessed 9 February 2018. https://www. gov.uk/government/uploads/system/uploads/attachment_data/file/603781/Council_tax_levels_set_by_local_authorities_in_England_2017-18.pdf

Department for Communities and Local Government. "Local Authority Revenue Expenditure and Financing: 2016-17 Final Outturn, England". Accessed 9 February 2018. https://www.gov.uk/government/uploads/system/uploads/attachment_data/file/659752/RO_Final_Outturn_2016-17_Statistical_Release.pdf

European Commission. "European Structural and Investment Funds: Country Data for United Kingdom”. Accessed 9 February 2018. https://cohesiondata. ec.europa.eu/countries/UK

European Commission. "Evaluations of the 2007-2013 programming period". Accessed 15 November 2017. http://ec.europa.eu/regional_policy/en/policy/evaluations/ec/2007-2013/

European Commission. "Simplifying Cohesion Policy for 2014-2020". Accessed 9 February 2018. http://ec.europa.eu/regional_policy/sources/docgener/informat/2014/simplification_en.pdf

Evans, Geoffrey and Anand Menon. Brexit and British Politics Cambridge: Polity Press, 2017.

Goldsmith, Mike and Elizabeth Sperling. "Local governments and the EU: the British experience", in European Integration and Local Government, edited by: Mike Goldsmith and Kurt Klausen. Cheltenham: Edward Elgar, 1997.

Hastings, Annette, Nick Bailey, Glen Bramley, Maria Gannon and David Watkins. The Cost of the Cuts: The Impact on Local Government and Poorer Communities York: Joseph Rowntree Foundation, 2015.

HM Government. "Further certainty on EU funding for hundreds of British projects". Accessed 9 February 2018. https://www.gov.uk/government/news/further-certainty-on-eu-funding-for-hundreds-of-british-projects

HM Government. "Industrial Strategy: building a Britain fit for the future". Accessed 9 February 2018. https://www.gov.uk/government/publications/industrialstrategy-building-a-britain-fit-for-the-future

Huggins, Christopher. "Local Enterprise Partnerships and the Development of European Structural and Investment Fund Strategies in England". European Structural and Investment Funds Journal 2, No. 2 (2014): 183-189.

Huggins, Christopher. "Subnational transnational networking and the continuing process of local-level Europeanization”. European Urban and Regional Studies OnlineFirst (2017).

Industrial Communities Alliance. Post-Brexit Regional Policy: Proposal from the Industrial Communities Alliance Barnsley: Industrial Communities Alliance, 2017. 
John, Peter. "Europeanisation in a centralising state: multi-level governance in the UK”. Regional and Federal Studies 6 No. 2 (1996): 131-144.

Johnson, Neil. 'Purdah' before elections and referendums London: House of Commons Library, 2017.

Jones, Andrew. "Here We Go Again: The Pathology of Compulsive Re-organisation", Local Economy, 25, No. 5-6 (2010): 373-378.

Local Government Association. "Beyond Brexit: Future of Funding Currently Sources from the EU". Accessed 9 February 2018. https://www.local.gov.uk/beyond-brexit-future-funding-currently-sourced-eu-lga-discussion-document

Local Government Association. "Briefing, Leaving the European Union". Accessed 4 July 2016. http://www.local.gov.uk/web/guest/media-releases/-/journal_content/56/10180/7870973/NEWS

Local Government Association. "Briefing, Local Government Association, Brexit". Accessed 9 February 2018. https:/www.local.gov.uk/sites/default/files/documents/lga-briefing-local-govern-0ff.pdf

Local Government Association. "UK-EU joint report: Phase 1 Negotiations Briefing”. Accessed 9 February 2018. https://www.local.gov.uk/sites/default/files/documents/2017\%2012\%2011\%20LGA\%20briefing\%20-\%20EU\%20 Phase $\% 201 \% 20$ agreement $\% 20$ briefing\%20\%28002\%29.pdf

Local Government Association. "'Urgent clarity' needed on EU funds, councils warn”. Accessed 9 February 2018. https://www.local.gov.uk/about/news/urgent-clarity-needed-eu-funds-councils-warn

Local Government Association. "What the Manifestos Say 2017: Brexit, Devolution and Constitutional Reform". Accessed 9 February 2018. https://www.local.gov.uk/sites/default/files/documents/9\%2038\%20LGA\%20MANIFESTO_ BREXIT_v02_1\%20\%28002\%29-4.pdf

Marshall, Adam. "Europeanization at the urban level: Local actors, institutions and the dynamics of multi-level interaction", Journal of European Public Policy 12, No. 4 (2005): 668-686.

Morgan, Kevin. "Re-inventing regional policy for post-Brexit Britain". Accessed 9 February 2018. http://blogs.cardiff.ac.uk/brexit/2017/04/26/re-inventing-regional-policy-for-post-brexit-britain/

Northern Ireland Local Government Association. "EU Referendum Outcomes NILGA Position Paper”. Accessed 9 February 2018. http://www.nilga.org/getattachment/c7253dae-010e-4d6e-8013-d84c70ac4933/EU-Referendum-Outcomes---NILGA-Position-Paper.aspx.

Prosser, Brenton, Alan Renwick, Arianna Giovanni, Mark Sandford, Matthew Flinders, Will Jennings, Graham Smith, Paolo Spada, Gerry Stoker and Katie Ghose. "Citizen Participation and Changing Governance: Cases of Devolution in England". Policy and Politics 45, No. 2. (2017): 251-269.

Pugalis, Lee. "Sub-national economic development: Where do we go from here?". Journal of Urban Regeneration and Renewal, 4, No. 3 (2011): 255-268.

Pugalis, Lee. "The Regional Lacuna: A Preliminary Map of the Transition from Regional Development Agencies to Local Enterprise Partnerships", Regions, 281 (2011): 6-9. 
Pugalis, Lee and Ben Fisher. "English regions disbanded: European funding and economic regeneration implications". Local Economy 26, No. 6-7 (2011): 500-516.

Pugalis Lee and Adam Townsend. "Rebalancing England: sub-national development (once again) at the crossroads". Urban Research and Practice, 5, No. 1 (2012): 157-174.

Sandford, Mark. Combined authorities London: House of Commons Library, 2016.

Sandford, Mark. Devolution to Local Government in England London: House of Commons Library, 2016.

Sykes, Olivier and Andreas Schulze Bäing. "Regional and Territorial Development Policy after the 2016 EU Referendum - Initial Reflections and some Tentative Scenarios". Local Economy 32, No. 3 (2017): 240-256.

Welsh Local Government Association. "Collating Local Impact of Brexit, Spring 2017”. Accessed 9 February 2018. http://www.wlga.wales/SharedFiles/Download .aspx ?pageid $=62 \&$ mid $=665 \&$ fileid $=1178$.

\section{About the author}

Dr Christopher Huggins is a Research Fellow at the University of Aberdeen and Teaching Fellow in European Politics at Keele University. His overall research interests cover the relationship between the European Union (EU) and the subnational levels. In particular, his research focuses on the role of subnational transnational networking in EU governance, the impact of Brexit on English local government and the impact of Brexit on the devolution of fisheries policy in the UK. His most recent publications include 'Subnational transnational networking and the continuing process of local-level Europeanization', published in European Urban and Regional Studies, and 'Subnational government and transnational networking: the rationalist logic of local level Europeanization' which is forthcoming in the Journal of Common Market Studies. See also: https:// www.abdn.ac.uk/socsci/people/profiles/christopher.huggins.

\section{Sobre el autor}

Dr Christopher Huggins es investigador en la Universidad de Aberdeen y profesor de Política Europea en la Universidad de Keele. Su interés de investigación se centra fundamentalmente en las relaciones entre la Unión Europea (UE) y los niveles sub-nacionales. En particular, su trabajo investigador se focaliza en el papel de las redes trasnacionales de entes sub-nacionales en la gobernanza de la UE, el impacto del Brexit en el gobierno local inglés y los efectos del Brexit sobre la devolución de la política pesquera al Reino Unido. Sus publicaciones más recientes incluyen, 
entre otros títulos, "Subnational transnational networking and the continuing process of local-level Europeanization", publicado en la revista European Urban and Regional Studies, y "Subnational government and transnational networking: the rationalist logic of local level Europeanization", que se publicará próximamente en la revista Journal of Common Market Studies. Más información:https://www.abdn.ac.uk/socsci/people/ profiles/christopher.huggins. 


\section{Derechos de autor}

Los derechos de autor (para la distribución, comunicación pública, reproducción e inclusión en bases de datos de indexación y repositorios institucionales) de esta publicación (Cuadernos Europeos de Deusto, CED) pertenecen a la editorial Universidad de Deusto. El acceso al contenido digital de cualquier número de Cuadernos Europeos de Deusto es gratuito inmediatamente después de su publicación. Los trabajos podrán leerse, descargarse, copiar y difundir en cualquier medio sin fines comerciales y según lo previsto por la ley; sin la previa autorización de la Editorial (Universidad de Deusto) o el autor. Así mismo, los trabajos editados en CED pueden ser publicados con posterioridad en otros medios o revistas, siempre que el autor indique con claridad y en la primera nota a pie de página que el trabajo se publicó por primera vez en $C E D$, con indicación del número, año, páginas y DOI (si procede). Cualquier otro uso de su contenido en cualquier medio o formato, ahora conocido o desarrollado en el futuro, requiere el permiso previo por escrito del titular de los derechos de autor.

\section{Copyright}

Copyright (for distribution, public communication, reproduction and inclusion in indexation databases and institutional repositories) of this publication (Cuadernos Europeos de Deusto, CED) belongs to the publisher University of Deusto. Access to the digital content of any Issue of Cuadernos Europeos de Deusto is free upon its publication. The content can be read, downloaded, copied, and distributed freely in any medium only for non-commercial purposes and in accordance with any applicable copyright legislation, without prior permission from the copyright holder (University of Deusto) or the author. Thus, the content of $C E D$ can be subsequently published in other media or journals, as long as the author clearly indicates in the first footnote that the work was published in $C E D$ for the first time, indicating the Issue number, year, pages, and DOI (if applicable). Any other use of its content in any medium or format, now known or developed in the future, requires prior written permission of the copyright holder. 